DOI: $10.30520 /$ jjosci.920636

\title{
THE DIVERSITY OF GERMAN TOP ORGANISATIONS' WEBSITES AND SOCIAL MEDIA
}

\author{
Lara Lüthgens, B.A. ${ }^{1}$ \\ Prof. Dr. Dominik Pietzcker ${ }^{2}$
}

\begin{abstract}
Considering the potential impact diverse and not diverse communication could have on an organisation's stakeholders there is a lack of research about how diversity is communicated externally by organisations. Different studies have shown that gender-neutral language can positively influence peoples' attitudes towards members of the LGBTQIA+ community and that pictures can have a significant influence on their recipients. Therefore, the goal of this article is to find out how diverse the communication of organisations in Germany is. Through a quantitative analysis of media content, the websites and Instagram accounts of twelve German companies chosen through a ranking of Germany's best employers are analysed. The study's results show that the external communication of the analysed companies is not yet completely diverse, that there are differences between the diversity communication on the companies' websites and on social media and that the company size doesn't seem to be connected to the level of diversity. Furthermore, some companies are starting to adapt gender-neutral language and also show symbols that show support of the LGBTQIA+ community. Ultimately, the study shows that companies still need to improve on some levels, especially regarding the representation of people with disabilities and members of the LGBTQIA+ community, until their communication can really be seen as diverse - and until they will potentially have an impact on their stakeholders.
\end{abstract}

Keywords: Diversity, Inclusion, Communication, LGBTQIA+, People with disabilities

\footnotetext{
${ }^{1}$ Lara Lüthgens, B.A., finished her studies in Media Management at Macromedia University of Applied Sciences, Hamburg. She is preparing for a Masters' degree in International Relations.

E-mail: lara.luethgens@gmx.de

${ }^{2}$ Since 2012, Dominik Pietzcker, Dr. phil., is a fulltime professor at Macromedia University of Applied Sciences, Hamburg and Berlin Campuses and a member of the Media Faculty. He studied comparative German literature, philosophy and history at the University of Freiburg/Br., Trinity College Dublin and in Vienna. Since 2014, he is an honorary juror at the Foundation of German Entrepreneurs (Stiftung der Deutschen Wirtschaft, SDW). Since 2017 he holds lectures at Zheijang University City College (Hangzhou) and Tongji University (Shanghai). He publishes regularly on intercultural, Sino-German, and socio-economic topics. E-mail: d.pietzcker@macromedia.de https://orcid.org/0000-0002-1420-9396.
} 


Yhe
$\begin{aligned} & \text { Journal of } \\ & \text { Social } \\ & \text { Science }\end{aligned}$

\section{INTRODUCTION}

A 2020 study of the Charta der Vielfalt shows that $46 \%$ of the participating companies already have diversity measures implemented or planned. $63 \%$ of respondents noted that they expect the relevance of diversity management to increase even further in the future (Charta der Vielfalt, 2020). It seems therefore, that diversity management, a term coined in the United States of America by the two researchers Cox and Blake, continues to gain more importance not only in the USA, but also in Germany (Süß, 2008).

Looking at diversity in German companies however, it seems that equality has not yet been reached by far. Within the last 5 years for instance, in the 100 largest German companies there has been a decrease in the share of foreign CEOs from 15\% to about 10\%, while only two percent of the CEOs were women (Ettel \& Zschäpitz, 2020). In addition, only a small share of people with disabilities in Germany is employed (Bundesagentur für Arbeit, 2019). Furthermore, not all homo-, bi- or transsexuals do seem comfortable showing their real identity at their workplace, although this share has improved over the last years (Bell, Özbilgin, Beauregard \& Sürgevil, 2011; Antidiskriminierungsstelle des Bundes, 2017). In addition to a lack of diverse people in leadership and employment in general, there seems to be a lack of representation of - among others - females, people of colour, people with disabilities and LQBTQIA+ individuals in communication about and of companies. This was the starting point to find out more about the diversity of the communication of German companies.

The question of the diversity of organisations' communication becomes even more interesting once looking at the potential effects it can have on a company's stakeholders. Several studies have found that companies which engage in diversity management do so because of employee attraction and the impact it can have on their image (Ravazzani, 2016; Charta der Vielfalt, 2020). Furthermore, the extend of diversity, meaning the presence of people of different gender, ethnicity, sexual orientation, age and of other attributes, can influence consumer behaviour (Onlinemarketing.de, 2020). Lastly, the results of some research suggest that gender-inclusive language can influence positive perception towards members of the LGBTQIA+ community (Gustafsson Sendén, Bäck \& Lindqvist, 2015; Tavits \& Pérez, 2019; Bradley, 2020). If the impact of imagery on its recipients is comparable to the one of inclusive language, the impact on an organisation's stakeholders could be negative if they see that certain individuals are not included in the communication. Therefore, the study presented in this article aims at finding out how diverse the external communication of German organisations is.

Even though there has been an increasing extent of research about internal diversity management strategies in the last decades (e.g. Pless \& Maak, 2004; Nishii \& Özbilgin, 2007; Hayles, 2014; Maier \& Ravazzani, 2019) there is a surprising lack of studies about how companies and organisations communicate their efforts of diversity, or rather, express their diversity externally to their customers and stakeholders in general (Maier \& Ravazzani, 2019). Furthermore, Ravazzani (2016) proposes that the conducted research in the field of diversity management concentrates on diversity management in the USA and on gender issues. Therefore, it seems that there is a lack of research about diversity management in Europe and about people of colour, people with disabilities and LGBTQIA+ issues. Bell et al. (2011) come to a similar conclusion, mentioning the focus on race and sex in diversity studies. Specifically in Germany the focus of diversity management has layn mainly on gender, as Hansen (2014) observes. This finding is confirmed by different market studies (Roland Berger Stragegy Consultants, 2012; Völklinger Kreis, 2015). This article is therefore written with the goal of starting to fill these gaps in research with a focus on the external communication of diversity of organisations in Germany, analysing not only gender equality but also if people of colour, people with disabilities and members of the LGBTQIA+ community are included in the communication. 


Year:5, Volume:5, Number:10/2021
$\begin{aligned} & \text { The } \\ & \text { Social } \\ & \text { Science }\end{aligned}$

\section{Diversity and inclusion in organisations}

\subsection{Definitions of diversity and diversity management}

Before the diversity of companies' communication is assessed, we look at the definitions of the term diversity in different studies and at which attributes are included under the term.

Many attributes, such as age, gender, ethnicity and religion are mentioned in most studies about diversity (Von Bergen, 2002; Pless \& Maak, 2004; Nishii \& Özbilgin, 2007). Other characteristics are mentioned less frequent: When Pless and Maak (2004) defined diversity, they left out disability and sexual orientation, however they included the broader attributes education, lifestyle, working style and way of thinking. Ferdman (2014), has one of the broadest definitions of diversity in an organisational context. He describes diversity as "the representation of multiple identity groups and their cultures in a particular organization or workgroup" (p. 3). Nishii and Özbilgin (2007) finally, also count pregnancy as a factor that should be considered in diversity management. The German association Charta der Vielfalt (n.d.) has built a model with different attributes of diversity, sorted into three dimensions: an inner dimension, an outer dimension and the organisational dimension.

To sum it up and combine the different definitions, diversity in the context of diversity management can be defined as the presence of people of different demographics, physical conditions, sexual identities and ideologies.

As already mentioned previously, the focus of diversity management lies on race and gender in the USA and on gender in Germany. Hansen (2014) explains that the emphasis of diversity management on gender in Germany stems from the ubiquitous problem that women only very rarely reach top positions in German organisations and the organisations' efforts to solve this problem. Moreover, Hansen (2014) mentions the Allgemeine Gleichbehandlungsgesetzt (General equal treatment law) that forbids discrimination because of gender, age, disability or ability to perform, race, religion and sexual identity. According to the law, employees should be protected from discrimination that falls into the scope of the law - many of the attributes that were mentioned beforehand in different definitions of diversity and diversity management are included here. Nonetheless, pregnancy and the broader attributes listed by Pless and Maak (2004) are not considered in the law.

Diversity management itself means an organisation's strategy towards a more diverse workforce and includes initiatives and strategies towards a better cooperation within diverse teams, cultural intelligence and open-mindedness of the employees. It is also the process towards more employee equality, for instance regarding salary and promotion prospects (Vedder \& Krause, 2014). The overall goal of diversity management is described for example by Vedder and Krause: "Über allem stehen die juristisch-moralischen Ziele, niemanden zu diskriminieren, weitgehende Chancengleichheit herzustellen, fair und tolerant mit diversen Menschen umzugehen. Gemeinsamkeiten und Unterschiede sollen wahrgenommen, anerkannt, wertgeschätzt und als positive Beiträge zum Erfolg einer Organisation konstruktiv genutzt werden" (Vedder \& Krause, 2014, p. 62). Von Bergen, Soper and Foster (2002) describe diversity management similarly as a desire by organisations "to assure that no person or group is discriminated against based on age, race, gender, disability, ethnicity or religion" (p. 239). The goal according to them is "to create a positive work environment for all employees" (Von Bergen, Soper \& Foster, 2002, p. 239), because it "also entails recognizing, being open to, and utilizing human differences" (Von Bergen, Soper \& Foster, 2002, p. 239). Furthermore, Vedder and Krause (2014) mention some of the accelerators of diversity management. Accelerators of diversity management are the internationalisation of companies, competitive advantages through different language skills and cultural competences, the demographic change, altered expectations of recent generations, as well as legal requirements - such as the Allgemeine Gleichbehandlungsgesetzt that was already introduced above. 
A study by Deloitte (2015) observed an interesting difference between how different generations define diversity: "millennials have substantially different perspectives on diversity and inclusion than older generations" (Deloitte, 2015, p. 19). Millennials seem to be more open-minded towards diversity and also have a broader definition of the term. Finally, there might be companies and managers that engage in diversity management out of intrinsic values, but other reasons to include diversity management in a company's strategy are the ones mentioned above, as well as the potential possible effects of diversity management (Vedder \& Krause, 2014), which are discussed in the following chapter.

\subsection{Potential impacts of diversity management}

The question of why organisations want to engage in diversity management is covered in different studies and surveys, for example in a study by McKinsey \& Company (2018): "Many successful companies regard I\&D as a source of competitive advantage. For some, it's a matter of social justice, corporate social responsibility, or even regulatory compliance. For others, it's essential to their growth strategy" (p. 4). Pless and Maak (2004) too see the possibility that diversity can help an organisation on the way to a competitive advantage. As a reason they name the "search for original problem solutions, innovative product ideas and targeted marketing initiatives" (p. 130) that diverse teams excel at. Similarly, Vedder and Krause (2014) suppose that real innovations need diverse teams in which different competencies and approaches lead to new ideas. A recent diversity study conducted by the Charta der Vielfalt (2020) also shows different reasons for German organisations to engage in diversity management. Participants rated which potential advantages of diversity management were the most important for their company: The advantage rated as most important was to become more attractive for talents, followed by gaining more open-mindedness and capability to learn in the company as well as increasing employee satisfaction. Further reasons were encouragement of innovation and creativity and reacting to the changes in society. Also, compliance, showing CSR, and inclusion of external stakeholders were named as advantages for the companies. The impact of diversity management on employer attractiveness was analysed in a paper by Stangel-Meseke, and she found that "both women and minorities ascribe a high priority to the aspect of diversity and that it influences their evaluation of an employer significantly" (Stangel-Meseke, 2017, p. 199). Furthermore, intertwining the concepts of diversity management and corporate social responsibility, or rather, classifying the two as connected, Stangel-Meseke observes that each of the two concepts influences a positive image of the company. Nishii and Özbilgin (2007) mention several positive impacts of organisations' diversity management, such as better firm performance and an increased employee engagement, as well as higher job satisfaction and augmented employee commitment.

A study by PageGroup (2018) with 139 German employees who are responsible for diversity management, found that their diversity efforts let to internal as well as external benefits and successes. Regarding internal successes, $59.7 \%$ of the employees reported better cooperation in teams, $43.5 \%$ a stronger commitment to the company, $41.9 \%$ an increased employee satisfaction and lastly, $21.0 \%$ reported an increased innovation rate. External changes that were reported by diversity representants include higher attractivity for applicants regarding employer branding (reported by $69.4 \%$ ), an improved image (reported by 48.4\%), development of new markets and customer segments (reported by 17.7\%) and finally, $9.7 \%$ noticed an increase in turnover.

While there are several studies which support a positive correlation between diversity management and company performance, critics of diversity management propose otherwise: "other studies indicate that diversity might lead to poor performance as a result of conflict" (Hansen \& Seierstad, 2017, p. 13). This might be the case when the diversity management strategy is not taken seriously enough or not really accepted within the company. The researchers Pless and Maak for example, propose that "diversity management will not unleash any potential benefits unless diversity is culturally valued" (p. 130). Potential and unintended negative effects of diversity management are examined in the research of Von Bergen, Soper and Foster (2002). These negative results include reversed discrimination, demoralisation, increased legal liabilities and even reinforcement of stereotypes. Nonetheless, in their 
conclusion and summary the researchers emphasise that diversity management can indeed lead to an achievement of the expected positive outcomes, if it is properly approached. According to their research one important factor of properly handling diversity management is the following: "The process should become a standard way of doing business as opposed to just a short-lived, one-time process" (Von Bergen, Soper \& Foster, 2002, p. 248). Still, they mention that next to long-term goals also short-term goals are needed to be successful. Furthermore, the researchers explain that the definition of diversity shouldn't be too narrow, that support of the top management is crucial and finally, that "it must be based on inclusiveness" (Von Bergen, Soper \& Foster, 2002, p. 248).

\subsection{Gender-neutral language $\&$ diverse imagery}

There are languages that mark nouns and/or pronouns according to gender, as well as genderless languages that mark neither. In some languages that mark gender, such as English or German, the language is based on a binary system, marking words either as male or female. Consequently, there is no linguistic representation of gender for the people that don't (exclusively) identify as male or female (Bigler \& Leaper, 2015). Nouns that mark gender in English are for instance woman, man, and pronouns her, his - in German it is very similar with nouns such as Frau, Mann and pronouns like er, sie. However, gender-neutral nouns do exist, e.g. child, spouse, student in English, or Kind in German. Regarding the pronouns however, there is no gender-neutral alternative. Furthermore, in many languages that mark gender, the so-called generic masculine is used, which is the use of masculine nouns or pronouns to refer to all people (Bigler \& Leaper, 2015). In German, the equivalent would be to say Mitarbeiter ((male) employee) to refer to all employees, male and female, instead of including the female version Mitarbeiterin (female employee). The problem with the generic masculine is that people often interpret it to refer to males rather than females. In addition, it implies a higher status of the male gender (Bigler \& Leaper, 2015).

Gender-neutral terms present alternatives that don't mark the gender of the subject as either male or female, often in plural form - in the case of the words Mitarbeiter and Mitarbeiterin for instance, these would be Mitarbeiterschaft, Belegschaft or Kollegium (Duden, 2020a). Other words, like Mitarbeitende and Studierende become more and more accepted as gender-neutral alternatives for the male and female forms of the words (Duden, 2020b). Such gender-neutral forms are needed for example, in situations where one wants to address all people inclusively, instead of only males and/or females, is transgender or when the individual that is referred to doesn't identify binarily as male or female. For cases where no such neutral word forms exist in the German language there have been different attempts to create ways around it, as there have been in other languages too. For instance, through the use of capital letters within a word: The so-called Binnen-I that combines the male and female noun by adding the female ending in in the singular or -innen in the plural form with a capital $I$ - for example, the German word for employee with the Binnen-I would be MitarbeiterIn. Studies about the Binnen-I have shown, that its use can lead to an overrepresentation of females in thoughts, which implies that it might not be an ideal gender-neutral word form (Ivanov, Lange, Tiemeyer \& Ptok, 2019). Other versions of inclusive language use symbols to combine the male and female word forms, also all by adding the female word ending to the male one. Examples are the use of a forward slash (e.g. Mitarbeiter/in) or of brackets (e.g. Mitarbeiter(in)), the latter of the two being criticised for including the female form only as an appendage. Moreover, all of these presented forms merely include the female word and thus stay within the gender binary (Ivanov, Lange, Tiemeyer \& Ptok, 2019).

In order to also include people that fall outside of the male-female dichotomy, more inclusive word forms have been created in the German language: As Ivanov, Lange, Tiemeyer and Ptok (2019) explain, nouns containing the gender gap (e.g. Mitarbeiter_in) include a symbolic gap which represents all the possible gender identities aside from female and male. The gender star (Genderstern, Gender*stern or Gendersternchen in German) serves the same symbolic purpose, where the rays of the asterisk embody the different non-binary gender identities (e.g. Mitarbeiter*in). The gender gap and especially the 
gender star have become relatively popular in Germany, being used for example by political parties and, because of a local decision, by the city of Hannover (Ivanov, Lange, Tiemeyer \& Ptok, 2019). Kolek (2019) examined the media coverage about the gender star in German newspapers and came to the conclusion that there are heated discussions, ranging from extreme aversion of the asterisk, comparing it with "Vergewaltigung der deutschen Sprache ('a rape of the German language')" (p. 123) to praising its quick spread in the German language and calling it ",eine klare Bereicherung des deutschen Wortschatzes" ('a clear enrichment of the German vocabulary'..." (p. 122). An even more recent form of gender-inclusive language is the Gender:Doppelpunkt (e.g. Mitarbeiter:in) which is now officially used by the German city of Lübeck, if there is no neutral alternative (Offizielles Stadtportal der Hansestadt Lübeck, 2019). Even in scientific writing gender-inclusive language is used by now. The guide for scientific writing by Kipman, Leopold-Wildburger and Reiter (2018), for example, states that the visualisation of gender is common by now in scientific texts and even adds a guide for genderinclusive wordings. Similarly, in her guide for scientific writing, Doris Berger-Grabner (2016) recommends using male and female word forms or gender-neutral language, after having discussed it with ones' supervisor.

The Linguistic Relativity Hypothesis, also called Sapir-Whorf Hypothesis claims that language influences thought and perception. There are studies that support the hypothesis (e.g. Gentner, 2016), however, it remains subject to controversy (Al-Sheik Hussein, 2012). Regarding diversity and inclusion, the hypothesis regains importance because of the (positive) impact that gender-neutral or genderinclusive language could have on existing sexist structures or negative perceptions against nonbinary people. A popular example supporting this theory is the introduction of the gender-neutral pronoun "hen" in addition to the feminine and masculine pronouns "hon" and "han" in Sweden, (see Gustafsson Sendén, Bäck \& Lindqvist, 2015; Bradley, 2020). The research of Gustafsson Sendén, Bäck and Lindqvist (2015) and more specifically the one of Tavits and Pérez (2019) imply that the introduction of such gender-neutral pronouns increase tolerance towards members of the LGBTQIA+ community, as well as positively shape attitudes towards them. The evidence of the study suggests that "genderneutral language can increase the acceptance of nonbinary LGBT individuals" (Tavits \& Pérez, 2019). Complementary to these findings, the study of Sczesny, Moser and Wood with around 400 German and Swiss participants suggests that people deliberately choose specific language according to their perceptions and ideology. The majority of the sample scored relatively low on the use of genderinclusive language and used masculine generics more often than the neutral alternatives (Sczesny, Moser \& Wood, 2015). Moreover, sexist participants could deliberately choose to not use gender-inclusive language, because they wish to stick to the language which embodies male norms. Referring to "women's access to resources and opportunities in the economy, education, health and politics" (Sczesny, Moser \& Wood, 2015, p. 952), another finding of the authors was that "the evidence of sexist language-use patterns in the present research is consistent with the continued prevalence of patriarchy in the countries of our sample" (Sczesny, Moser \& Wood, 2015, p. 952). However, due to the relatively small sample size, the representativity of this study can be questioned.

As pictures can have more of an impact on the recipient due to their key stimuli than texts can (Rössler, 2017) they also play an important role in organisations communication. Images published by an organisation can provide insights about how the organisation wants to be perceived and about its values and therefore one can speculate about how a picture might impact the organisations image. A study conducted by Censuswide on behalf of Shutterstock, a platform for stock photos, with about 2500 marketeers from 9 countries participating in the survey, shows an increased demand for diversity stock photos in advertising (Shutterstock premier, 2018). A study by GettyImages, which too is a company with a stock photo website, found that businesses in Germany increasingly search for photos that depict people from the LGBTQIA+ community. The search requests for the term 'transsexual' for example, increased by $200 \%$ (even though no indication was given regarding the time frame of the increase). Furthermore, the study revealed that $63 \%$ of consumers buy from brands that represent people that are alike to them and that $64 \%$ of the people think it is important that brands show diversity (Onlinemarketing.de, 2020). These results could implicate that companies are starting to use more 
diverse imagery on their websites. However, as the Censuswide study that was cited above suggests that the increased demand of diverse imagery is driven by advertising, this conclusion is not necessarily sustainable. Furthermore, one could expect that in Germany, due to the focus in diversity on gender rather than on people of colour, people with disabilities or people from the LGBTQIA+ community, there might be more representations of females on organisation's websites now than in the past, creating more equality between representation of males and females, but less of the other groups.

The study of Duff (2011) investigated how gender and race are showcased in pictures of annual reports of accounting firms in the United Kingdom. The research didn't only measure the number of times people of different gender and ethnicity were represented, but also their interactions and possible stereotypes. While the results of the study show an underrepresentation of women and people of colour, the researcher notes that it was less pronounced than in previous studies. Nonetheless, the hypothesis that there were stereotypes and inequalities visible in the pictures was supported by the research. For example, the study found that "pictures with only ethnic minorities are more likely to use a nonprofessional or indeterminate setting than a professional location" (Duff, 2011, p. 33). Lastly, the study found that companies seem to display diversity when addressing themselves to potential applicants, but less when addressing other stakeholders. In conclusion, it seems that the way companies represent gender and people of different ethnicities (and possibly also people with disabilities and from the LGBTQIA+ community) can tell a lot about how serious they take diversity measures and their diversity efforts - in addition to the potential impact it can have on the recipients of the communication.

\subsection{Organisations' communication channels}

Organisations use different communication and advertising channels to communicate with their external stakeholders. In the digital era, an organisations' website which in most cases is the organisations' first and main presence in the web - if it is not the marketplace itself - is the first address stakeholders will visit in order to find information, contact details or statements for investors (Lammenett, 2019). Social media takes another important position as a communication and advertising channel as a part of an organisations' social media marketing strategy. Presence on social media can be professional in form of social networks such as LinkedIn or the widely popular networks like Facebook, Twitter, Instagram, TikTok, YouTube and WeChat (Faßmann \& Moss, 2016; We Are Social, Hootsuite \& DataReportal, 2020). Generally, a website is composed with text and images, with rather more text than pictures, due to its mostly informational and commercial nature, but also because of its role in advertising regarding SEO (Lammenett, 2019). On social media however, there are many networks where images or videos play the main role. Instagram, the photo- and video-sharing community and one of the most popular and important social networks in the western world, is one of them (We Are Social, Hootsuite \& DataReportal). Faßmann and Moss (2016) describe that Instagram is particularly fitted to fulfil the goal of showcasing an organisations' brand identity and personality and thereby impacting the brand image especially well, due to its focus on aesthetic mise-en-scène.

Because of the high impact that imagery can have, as described in the previous chapter, the pictures a company chooses to share with its stakeholders can say a lot about the company's beliefs. In addition, the shared imagery could influence the image that stakeholders have about the company and - like inclusive language supposedly does - it could influence their perceptions. Instagram, as one of the most popular social networks with a focus of communication on pictures and videos (Faßmann \& Moss, 2016), therefore seems to be one of the most appropriate media to analyse an organisation's external communication. Furthermore, the fact that Instagram has an especially young target group, with more than two thirds of its German users under the age of 35 and more than one third even under the age of 25, is of note (NapoleonCat, 2021). As described above, the younger generation of millennials generally has not only a wider definition of diversity but is itself more supportive of diversity and inclusion than older generations might be (Deloitte, 2015). This could lead organisations to communicate diversity differently and particularly more boldly on Instagram than they do it on their website. 


\subsection{Criticism and potential impacts of communicating diversity}

Communication about diversity or in an apparently inclusive way does not always lead to stakeholders' approval: "Many critical scholars view communication in this context as mere 'window dressing' that allows organizations to pretend to appreciate a diverse workforce without, however, implementing practices that create genuine equal opportunities" (Trittin \& Schoeneborn, 2017, p. 11). This, however, rather seems to be a phenomenon within advertising, where the instrumentalization of feminism or feminist views with the goal of selling more products or services is nicknamed "purplewashing" (elDiario, 2016). Purplewashing can therefore be compared to the practice of greenwashing in marketing, where companies try to attain a sustainable or green image, without really being ecologically sustainable. However, there also can be advertisements that challenge female stereotypes and have a feminist tone, which through their authenticity seem to speak to the audience and are therefore very successful. This kind of advertising is also called female empowerment advertisement - or short: "femvertising" (Åkestam, Rosengren \& Dahlen, 2017).

One of the companies that coined the femvertising term is Dove with its Real Beauty campaigns. Nonetheless, with more and more attentive stakeholders, there seems to be a thin line between femvertising and purplewashing. This conclusion can be drawn from the critical feedback to one of Dove's campaigns of 2017, selling bottles in different shapes to represent the varieties of female bodies (Forbes, 2017). This finding suggests that the question of authenticity is exceedingly important in organisations' communication, regarding femvertising and probably diversity. This article doesn't provide the scope to analyse if the communication of the analysed companies is authentic, also because probably mostly the employees and stakeholders with more proximity to the company will be the ones to really assess if an organisation's efforts for diversity are intrinsic and authentic or not.

Finally, as Trittin and Schoeneborn (2017) mention, there are scholars who support diversity communication because of the impact it can have on its recipients - like the potential impact of inclusive language and pictures that was described above. This social construction of reality is described for instance by Bandura who describes that especially the television seems to have an influence on peoples' stereotypes: "Indeed, many of the shared misconceptions about occupational pursuits, ethnic groups, minorities, the elderly, social and sex roles, and other aspects of life are at least partly cultivated through symbolic modelling of stereotypes" (Bandura, 2001, p. 282). Taking into account this potential impact that stereotypical messages and communication can have, the need for a diverse communication increases even further - provided that the goal is to influence the recipients of the communication towards a more open-minded and inclusive mindset.

\section{Research Question, Method \& Study Design}

The central question of this article is how organisations express their (existent or non-existent) diversity and diversity management externally, on their websites and on social media. This leads to the study's research question: How do organisations in Germany communicate their diversity externally, on their websites and social media?

Hypothesis 1:

Hypothesis 2:

\section{Hypothesis 3:}

Hypothesis 4:
There is a difference in how organisations express diversity on their website versus on Instagram.

Even if organisations communicate in an inclusive way, the focus tends to be on inclusion of women, while there is less inclusion of people of colour and members of the LQBTQIA+ community, or people with disabilities.

The more employees the company has, the more diversity is communicated externally (through pictures, text or support of initiatives/foundations).

Companies with more employees have more internal diversity initiatives or external partnerships than companies with less employees. 
The hypotheses and research question, with their focus on communication of diversity in Germany and inclusion of people of colour, different gender, people with disabilities and from the LGBTQIA+ community, help the study to be distinctive from previous research in diversity management, that mostly focused on internal diversity management strategies, gender equality, diversity management in the USA and in US-American studies on people of colour, as described in previous chapters. In order to answer the research question and to verify or contradict the hypotheses, the external communication of different organisations has to be analysed. The method that allows this kind of analysis is a quantitative analysis of media content as in Rössler (2017), because one can analyse the relevant features of the qualitative content systematically and then quantify and measure the results. As Riffe, Lacy and Fico (2005) explain in their guidebook, to understand the potential effects which communication can have on its recipients, one needs to analyse the content. Rössler (2017) further describes the analysis of content as a quantitative, or better, standardised method that helps to reduce complexity and to find patterns and tendencies within the analysed elements. The deductive study design - starting with a theory and a hypothesis or several hypotheses (Berger-Grabner, 2016) - with the goal of showing the results through numbers (or codes), is an attribute of the quantitative method. The chosen method for this study therefore is a quantitative analysis of media content (Kipman, Leopold-Wildburger \& Reiter, 2018).

In order to analyse the external communication of companies in Germany in regard to diversity, the communication channels of the companies in question need to be examined. Because of the functions and aspects of websites and Instagram as organisations' communication channels this study will focus on analysing the websites and Instagram accounts (if existent) of German companies. Normally the different materials or media that are to be analysed are the population and samples (Rössler, 2017). However, as the different materials stem from the same companies, in this case, the study's population is all German organisations. Due to the limited scope of this article, only the communication of a small sample of 12 organisations' external communication will be analysed. In order to determine the sample unit that will be analysed, a ranking of Germany's best employers (Presseportal, 2020) was used. This ranking was chosen as it shows the top three organisations per company size (from companies with 50100 employees to organisations with more than 5000 employees). To fit the sample number, the first and second place of each size category are chosen for the sample. This makes the sample random in regard to company size and industry while ensuring a heterogenous sample and on the other hand allows a selection that only includes companies that are relevant in Germany. The companies chosen for the analysis of their external communication are shown in the following table 1, sorted by organisation size and their position in the best employer ranking, including hyperlinks to the organisations' websites and Instagram accounts. 
Table 1: Sample unit for the analysis of content sorted by organisation size and ranking

\begin{tabular}{|c|c|c|}
\hline Employees & First place & Second place \\
\hline$>5.000$ & $\begin{array}{l}\text { Techniker Krankenkasse } \\
\text { (Health insurance fund) } \\
\text { https://www.tk.de/techniker } \\
\text { https://www.instagram.com/die_tech } \\
\text { niker/ }\end{array}$ & $\begin{array}{l}\text { Siemens Healthcare GmbH } \\
\text { (Healthcare provider) } \\
\text { https://www.siemens-healthineers.com/de } \\
\text { https://www.instagram.com/siemens.healt } \\
\text { hineers/ }\end{array}$ \\
\hline $2.001-5.000$ & 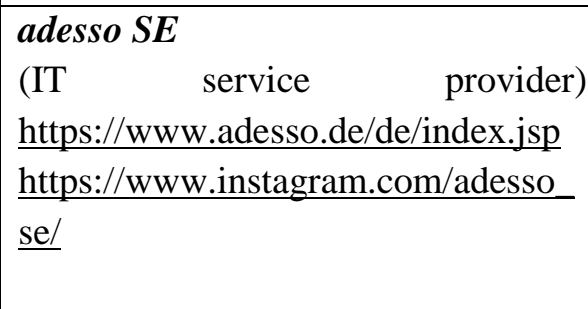 & $\begin{array}{l}\text { MARS GmbH } \\
\text { (German subsidiary of global food } \\
\text { company) } \\
\text { https://deu.mars.com } \\
\text { https://www.instagram.com/mars_karriere } \\
\text { ? } \mathrm{hl}=\mathrm{de}\end{array}$ \\
\hline 501-2000 & $\begin{array}{l}\text { DIS AG } \\
\text { (Personnel service provider) } \\
\text { https://www.dis-ag.com }\end{array}$ & $\begin{array}{l}\text { salesforce.com Germany GmbH } \\
\text { (CRM platform) } \\
\text { https://www.salesforce.com/de/ } \\
\text { https://www.instagram.com/salesforcede/ }\end{array}$ \\
\hline $251-500$ & $\begin{array}{l}\text { MaibornWolff GmbH } \\
\text { (IT consultancy) } \\
\text { https://www.maibornwolff.de } \\
\text { https://www.instagram.com/maiborn } \\
\text { wolff/?hl=de }\end{array}$ & $\begin{array}{l}\text { INERATEC GmbH } \\
\text { (Producer of synthetic fuels) } \\
\text { https://ineratec.de }\end{array}$ \\
\hline $101-250$ & $\begin{array}{l}\text { Pascoe pharmazeutische } \\
\text { Präparate GmbH } \\
\text { (Natural medicine provider) } \\
\text { https://www.pascoe.de } \\
\text { https://www.instagram.com/pascoe_ } \\
\text { naturmedizin/ }\end{array}$ & $\begin{array}{l}\text { QAware } \mathbf{G m b H} \\
\text { (IT consultancy) } \\
\text { https://www.qaware.de }\end{array}$ \\
\hline $50-100$ & $\begin{array}{l}\text { Spirit Link } \mathbf{G m b H} \\
\text { (Healthcare communication agency) } \\
\text { https://www.spiritlink.de }\end{array}$ & $\begin{array}{l}\text { Greator GmbH } \\
\text { (speaker and event agency) [Before name } \\
\text { change: GEDANKENtanken] } \\
\text { https://greator.com } \\
\text { https://www.instagram.com/greator/ }\end{array}$ \\
\hline
\end{tabular}

Note: Own Work

As this is a deliberate sample based on a choice of typical cases (Rössler, 2017) this method of sampling needs to be based on justifications: "Hier [choice of typical cases] wird aus dem Erkenntnisinteresse und den Forschungsfragen argumentativ abgeleitet, welche Auswahleinheiten mit Blick auf das Analyseziel besonders charakteristische Merkmale aufweisen" (Rössler, 2017, S. 63). As justifications Rössler (2017) names representants of media with an especially high audience, the so-called "Leitmedien" (Rössler, 2017, S. 63) that can influence the other media and lastly, a choice based on media of different orientations of content. Transferred to the sample of companies, the justification of the sample of this study is the ranking of Germany's best employers, because the companies can be seen as Germany's company leaders. Furthermore, the ranking includes companies of different industries, similar to the media with different orientations of content. 
The chosen organisations and their websites and Instagram accounts shown in table 1 will hence be the sample units. Rössler (2017) mentions that the effort is considerably higher if there are sample units of different media types, as it is the case in this study. Nonetheless, the results of a comparison between the organisation's communication on websites and Instagram justify the additional effort. The next subordinate unit of the sample units are the recording units. These will be the homepages, subpages, pictures on websites, as well as the posts on Instagram. The homepage is the main page of a company's website, often also accessed through a click on the company logo. Throughout the homepage one can access all key subpages, for instance via the main menu. Furthermore, under the definition of subpages of the website for recording unit 2 fall all pages of the website that are accessible through the website's main menu (on the top of the website or at the left or right side of the website). Only the direct subpages count to recording unit 2 , all pages that are subordinate to the subpages won't be subject to the analysis, as they mostly are the less important pages of a website, and the analysis of all pages of the websites would go beyond the scope of this article. The recording unit pictures on websites includes all pictures that can be found on the pages that fall under recording units 1 and 2. Lastly, the recording unit posts on Instagram includes the latest nine posts (only including posts with photos, none with videos) of the companies' Instagram accounts. Because of the different publishing frequencies of the sample companies on Instagram it was chosen not to have a time scope for the selection of posts. Instead the scope of the latest nine posts was chosen, as they are the first ones that are seen by a visitor of the companies' Instagram accounts. These four presented recording units are the elements that will be analysed in the coding process and they each have their own category system within the codebook.

The codebook states the rules about how to handle the content and how to code it. Moreover, it includes definitions for and statements about the content that will be analysed, and coding examples for the different categories. Thus, it includes all information that the coder (in this case the author of the article) needs for the coding process, including the instructions for the order of the coding process. The clear and precise definition of categories is important, as it improves the intra- and intercoder reliability, in order to not let changes of mood or different levels of knowledge of the same or different coders affect the result of the analysis or a repetition of the study (Rössler, 2017). Hence, the categories represent the exact definition of what is to be measured (Brosius, Koschel \& Haas, 2009). The codebook for this study includes, for instance, the category 'gender-inclusive language' with a definition and the codes for the manifestations of the category: [1 - Exclusive use], [2 - Partial use], [0 - No use] and [9 - Not applicable]. An example for the categories of the pictures on the webpages, is the category 'people in the picture' with the codes: [ 1 - Person / people in the picture], [0 - No person / people in the picture]. Another category analysing the characteristics of the pictures is 'diversity: people with disabilities'. Besides the definition of people with disabilities it specifies the codes: [1 - Only people without disabilities], [2 More people without disabilities than people with disabilities], [3 - Equal number of people with and without disabilities], [4 - More people with disabilities than people without disabilities], [5 - Only people with disabilities] and [9 - Not assignable]. A pattern in the codebook is that the codes [1] and [0] are used when something is or is not true - for example in the category of 'people in the picture' described above. The code [9] always stands for not applicable or not assignable.

Finally, in order for the data to be meaningful a comparison tool can be helpful, as it is used in the analysis of Duff (2011). For this study a survey of the German population (Statistisches Bundesamt, 2020a) will be used as a benchmark. The survey describes the German population of 2019 and the share of males and females, as well as of foreigners. The study of the Bundesagentur für Arbeit (2019) is used as a comparison tool for the share of people with disabilities. In order to have a benchmark for the share of LGBTQIA+ individuals the study of Dalia (2016) in which Europeans were asked about their sexual identity is used. 


Yhe
Journal of
Social
Science

\section{Interpretation of results}

During the analysis of media content 12 homepages, 309 subpages, 1718 pictures and 70 Instagram posts were analysed, respecting the rules of the codebook and saving the data in the coding form on excel. As described in a previous chapter, the survey about the German population of 2019 (Statistisches Bundesamt, 2020a) is used as a benchmark that allows a better understanding of what it means, when there is a specific share of women, people of colour or people with disabilities shown in pictures. The study shows that in Germany there are about 72.8 million Germans and about 10.4 million foreigners living in Germany. Regarding the Germans sex, there are about 35.5 million male Germans and about 5.5 million non-German males and 37.2 million German females and around 4.9 million non-German females. With a total population of about 83.2 million German residents the share of non-Germans is around $12.5 \%$. The share of females is $50.7 \%$. According to the study of Dalia (2016) the share of LGBTQIA+ individuals in Germany is about 7.4\%. The Bundesagentur für Arbeit (2019) study shows that the share of people with disabilities in Germany is 10.2 million people (and 7.8 million with grave disabilities), which is $12.2 \%$ (or $9.4 \%$ of people with grave disabilities) of the German residents. If companies aim to represent a share of males, females, non-whites, people with disabilities and LGBTQIA+ individuals which is representing the German population, the proportions should be similar to the ones of the studies. However, one should also consider that there are more men employed than women, with $83 \%$ of men and $75 \%$ of women being employed. Furthermore, not all foreign German residents are employed; according to the Statistische Bundesamt the proportion of foreign German residents being employed is $48 \%$ (Statistisches Bundesamt, 2018). Regarding people with disabilities only 1.2 million are employed, which is a share of about $12 \%$ of the German people with disabilities and around 1.4\% of the German population (Bundesagentur für Arbeit, 2019).

Hypothesis 1: There is a difference in how organisations express diversity on their website versus on Instagram.

In order to support or contradict the first hypothesis, one has to look at how diverse the different companies' communications are on the webpages and on the Instagram posts. Regarding gender, the pictures on the webpages are overall relatively diverse (see table 2, next page), showing a few more male than female individuals, which however fits the benchmark of the diversity of the German population.

On Instagram the diversity of the pictures regarding gender is similar, with more female individuals shown than male individuals (see table 2). Regarding the LGBTQIA+ community, overall there is no significant difference between the webpages and Instagram neither. Only two of 1299 pictures that show people contained symbols of the LGBTQIA+ community (which are $0.15 \%$ ), while none of the photos on Instagram included these kinds of symbols. Regarding people with disabilities neither photos on the webpages nor photos on Instagram show people with obvious physical disabilities. Looking at the individual companies and the pictures on their webpages and Instagram accounts there are more differences than in the average results. 
Looking at the language used on the websites and in the posts, while on the websites on only $2 \%$ of the subpages there is exclusive use of gender-neutral language and on $25 \%$ a partial use, on Instagram there is exclusive use of gender-neutral language on $11 \%$ of the posts and partial use on $22 \%$. Furthermore, while there is internal diversity commitment regarding gender equality, the LGBTQIA+ community, people with disabilities and people of colour on the subpages, on Instagram there were only two posts that mentioned internal diversity commitment for gender equality, but none for the other groups. These comparisons indicate that there is indeed a difference between the degree of diversity of the companies' websites and Instagram accounts, which would support and verify the hypothesis one. Nonetheless, because four of the companies don't have Instagram accounts and only 9 posts were analysed per existing account, the validity of the result is only partly conclusive, and the hypothesis 1 therefore only partly verified.

Table 2: Diversity (regarding gender) of the pictures on companies' Instagram accounts

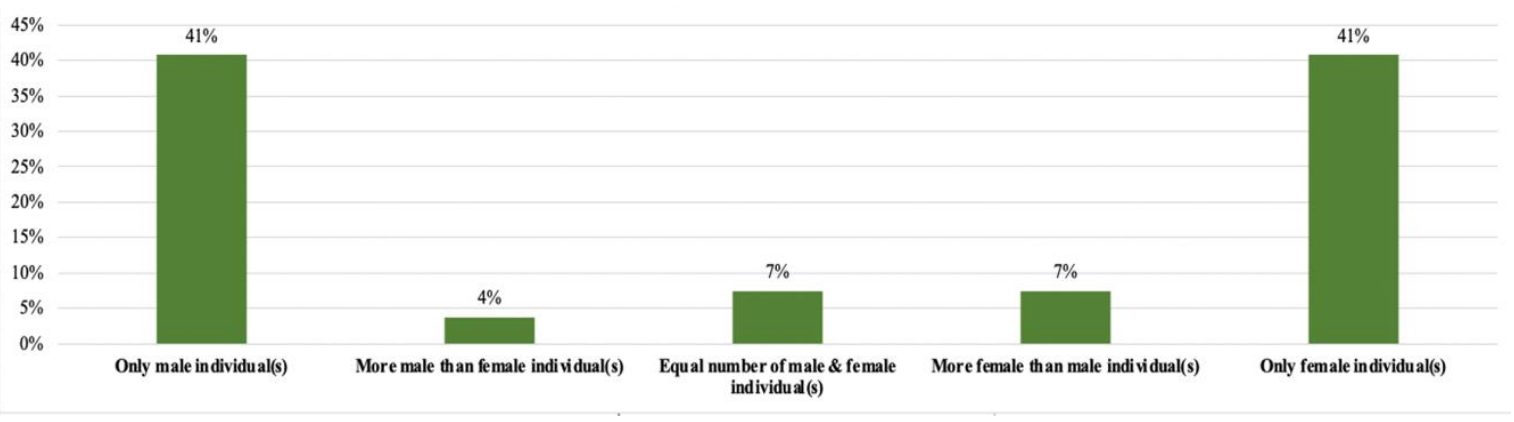

Note: Own work.

Hypothesis 2:

Even if organisations communicate in an inclusive way, the focus tends to be on inclusion of women, while there is less inclusion of people of colour and members of the LQBTQIA+ community, or people with disabilities.

Looking at the photos, overall the communication of the different companies is diverse regarding gender equality and therefore inclusive regarding women. Also, in regard to external and internal diversity commitment, there were more mentions of internal diversity commitment for gender equality, than for the other groups (LGBTQIA+, people with disabilities, people of colour).

Table 3: Diversity (regarding ethnicity) of the companies' websites

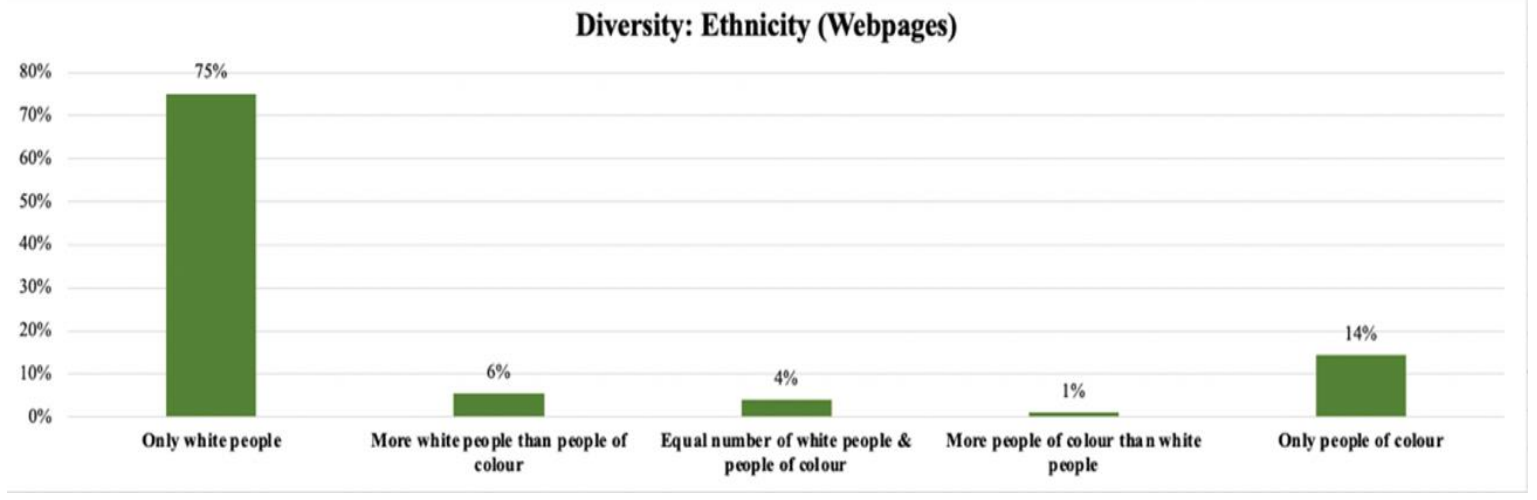

Note: Own work.

However, contrary to the hypothesis, looking at the pictures on the websites and on Instagram, the sample companies seem inclusive regarding people of colour (see table 3). So even though there is only one mention of internal diversity commitment for people of colour, the companies seem to be trying to 
be inclusive toward people of colour at least in pictures. Eight of the companies, except for adesso SE, MaibornWolff GmbH, INTERATEC GmbH and Spirit Link GmbH are showing a share of people of colour that is the same or even higher than the proportion of foreign residents in Germany. Regarding people with disabilities and the LGBTQIA+ community however, there are no photos showing people with disabilities and only two pictures showing LGBTQIA+ symbols. Furthermore, as described above, there are almost no internal diversity commitments for people with disabilities and from the LGBTQIA+ community (only two each). Thus, looking at the data, the second hypothesis can be partly verified regarding the focus on inclusion of women and less inclusion of people with disabilities and people from the LGBTQIA+ community in the communication. On the other hand, overall the companies are also focusing on the inclusion of people of colour, meaning that this part of the hypothesis is contradicted. In total, the second hypothesis is therefore partly verified.

\section{Hypothesis 3:}

The more employees the company has, the more diversity is communicated externally (through pictures, text or support of initiatives/foundations).

To verify or contradict the third hypothesis one has to look at the diversity of the different companies' communication and see if the companies with more employees use more inclusive language, have more diverse photos and more internal or external diversity commitments. While the two largest companies of the sample do not or almost not use gender-neutral language, MaibornWolff GmbH, which is part of the $3^{\text {rd }}$ smallest company size, has exclusive use of gender-neutral language on $6 \%$ of its subpages and partial use on $50 \%$ of the subpages. Also Spirit Link GmbH, belonging to the smallest company size, has partial use of gender-neutral language on $29 \%$ of the subpages. Thus, regarding the use of inclusive language, the hypothesis cannot be verified. Regarding the internal and external diversity commitments, the only companies mentioning internal diversity commitments are Siemens Healthcare GmbH, adesso SE, MARS GmbH and MaibornWolff GmbH, which are companies from the first and second largest, as well as the third smallest company size. Hence, also regarding the diversity commitments there doesn't seem to be a pattern of the larger the company size, the more diversity commitment. Lastly the pictures on the companies' webpages and Instagram accounts are looked at. As none of the companies is diverse regarding people with disabilities or people of the LGBTQIA+ community, only the diversity regarding gender and ethnicity can be an indicator regarding the diversity of communication compared to company size. The websites of the two companies of the largest employee size are diverse. Nonetheless, the Instagram page of Siemens Healthcare $\mathrm{GmbH}$ is not very diverse regarding women and people of colour, showing only white men on the published photos. Further, while the Instagram page of adesso SE which is of the second largest company size is diverse, its website is diverse regarding gender, but not regarding ethnicity, with more than $96 \%$ of the pictures showing white people (see table 4).

Table 4: Diversity (regarding ethnicity) on the website of adesso SE

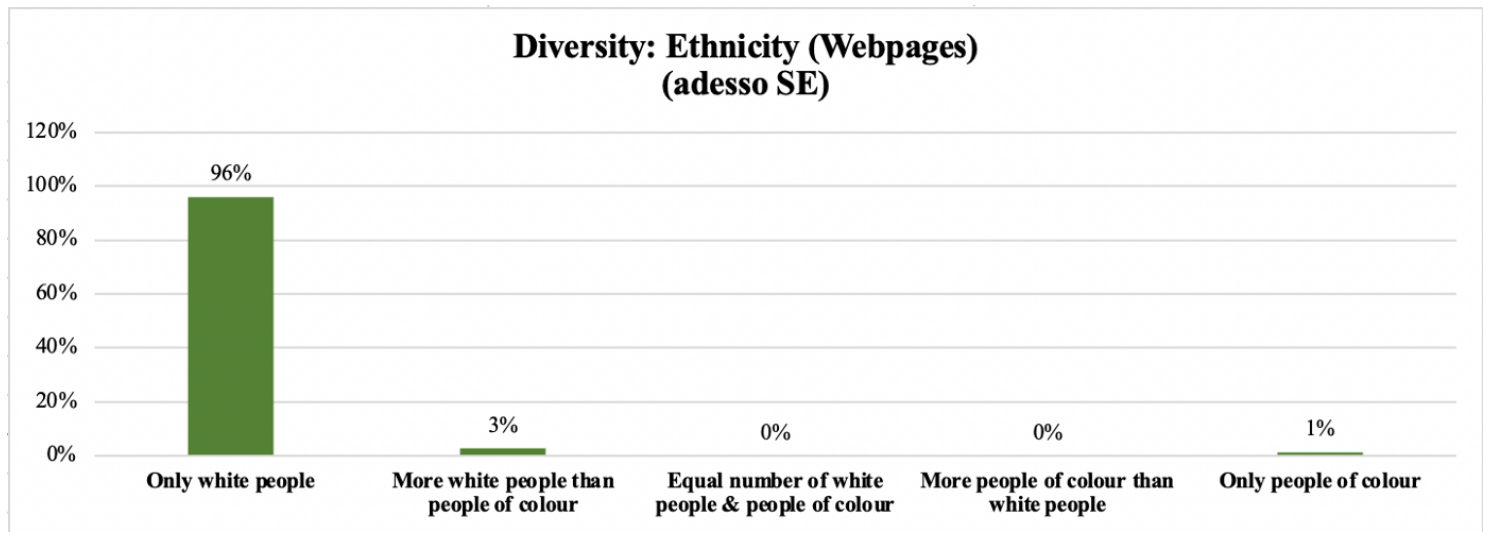

Note: Own work. 
Coming to the second smallest company size, the website of Pascoe pharmazeutische Präparate GmbH is diverse in regard to ethnicity, however regarding gender there is a significantly larger share of female than male individuals - this could be a result from the companies' efforts to include more female individuals and increase and promote gender equality. On the website of $Q A$ ware $G m b H$ it is the other way around, with a larger share of male than female individuals shown in the pictures. All in all, even though some of the smaller companies have less diverse pictures on their websites and Instagram, this is also the case for some of the larger companies. Hence, taking into consideration the use of inclusive language, diversity commitments and the diversity of pictures, the hypothesis three cannot be verified and is thus contradicted.

Hypothesis 4: $\quad$ Companies with more employees have more internal diversity initiatives or external partnerships than companies with less employees.

As described above, there are four out of the twelve companies that mention internal diversity commitments: Siemens Healthcare GmbH (for gender equality, the LGBTQIA+ community, people with disabilities and people of colour), adesso SE (for gender equality), MARS GmbH (for gender equality and the LGBTQIA+ community) and MaibornWolff GmbH (for gender equality and people with disabilities). They are of the first largest (Siemens Healthcare GmbH) and second largest (adesso $S E$ and MARS GmbH) as well as the third smallest (MaibornWolff GmbH) company size. Consequently, there is no pattern of the more employees the more diversity commitment, which contradicts the hypothesis 4 .

To sum it up, hypothesis 1 and 2 are partly verified while hypotheses 3 and 4 are contradicted. Finally, also the research question, 'How do organisations in Germany communicate their diversity externally, on their websites and social media?' can be partly answered. The verification and contradiction of the hypotheses merely give indications regarding the analysed companies, as the sample was not representative. For the organisations that were part of the sample however, the research question can be answered as follows: The analysed German organisations express their diversity differently on their website versus on Instagram, with a general focus on inclusion of women and people of colour, while people with disabilities or symbols of the LGBTQIA+ community are almost not shown at all. Inclusive language seems to become slowly adapted by some companies, but the majority of the organisations mostly doesn't use gender-inclusive language. Finally, the companies' number of employees, or size, doesn't seem to influence their diversity communication.

\section{Discussion of results}

Companies already seem to take advantage of the difference between the purpose and attributes of websites and Instagram regarding how they use inclusive language on the two, seeing that there were more cases of exclusive use of gender-neutral language on Instagram than on the websites. If there are companies that want to try being bolder regarding the diversity of their communication, a recommendation could be for them to try this strategy on Instagram first, where the younger recipients might be more open-minded towards this diversity. Moreover, companies that focus their diversity strategy on their website in order to attract talents should reconsider and redirect their efforts evenly to both their website and social media. Previously, also the matter of authenticity was briefly addressed in the context of CSR and purplewashing, especially its increasing importance in companies' communication. The differences that were noticed between different companies' websites and social media accounts could be seen as a lack of authenticity. If stakeholders notice on a long-term basis, that a company has a diverse communication on Instagram but not on its website, it could indicate that the communication is not authentic. Therefore, while companies could try different strategies on social media and on their website, the differences shouldn't be too striking, in order not to create a dichotomy between Instagram and the website. 
Furthermore, this study addresses the issue that companies don't seem to focus on people with disabilities and members of the LGBTQIA+ community in their diversity strategy (or that the respective companies don't have a real diversity management strategy). While people of different gender and ethnicity were shown relatively equally regarding their share within the German population this wasn't the case for people with disabilities and symbols of the LGBTQIA+ community. As discussed in a previous chapter, people look for brands and companies which represent people that look like them and would even boycott them if their communication is not diverse enough (Onlinemarketing.de, 2020). Furthermore, applicants actively search for diverse companies. Therefore, if companies want to attract really diverse talents and profit from all the advantages that diverse teams potentially have for companies, they should dare to represent diverse people, including people with disabilities. As it was explained in several studies about inclusion however, the importance of inclusion shouldn't be forgotten in the process. Hence, companies should see their diverse team and diversity management as a part of a long-term strategy which needs effort and support from the whole company.

Regarding the use of gender-neural language, there is still a lot of debate about inclusive language that uses symbols like the Genderstern or the Gender:Doppelpunkt, as described by Kolek (2019). Yet, there also is a way to use gender-neutral language without these symbols through the use of neutral words like Mitarbeitende or Studierende which were presented previously. A recommendation for companies is therefore to use more gender-neutral words like these, especially to replace the generic masculine for the German word for employee, Mitarbeiter. That way companies can start to be more gender-inclusive in their language, without having to use somewhat controversial versions of gender-inclusive language with the Genderstern or Gender:Doppelpunkt. If companies have a younger target group and younger stakeholders, or are in a specific industry, they could also be bold enough to only use gender-inclusive language, even with the Gendersternchen or Gender:Doppelpunkt. That way organisations can make a statement and create an open-minded image and could even use a more inclusive way of communicating to convey a brand identity.

Coming to hypothesis three, its contradiction indicates that diversity communication is not dependent on company size, which is a good sign for people supporting more diversity. Still, the analysis of the companies' websites and Instagram accounts and the discussion of the second hypothesis revealed that companies can indeed improve their diversity communication, regarding people with disabilities, members of the LGBTQIA+ community and inclusive language. The contradiction of hypothesis three therefore also shows that this improvement is not only due for the smaller companies, but indeed for companies of all sizes.

Lastly, there were only four of the twelve companies that mentioned internal diversity commitments, and none of the analysed organisations had external partnerships with initiatives for more inclusion of diverse people. However, a declaration on the website like "LGBTQIA+ welcome", as on the website of Siemens Healthcare GmbH can demonstrate openness of an organisation upfront. A declaration such as "we signed the Charta der Vielfalt" or "we adhere to the Charta der Vielfalt" could have a similar impact. On the website of the Charta der Vielfalt one can search for the companies which signed the charter and actually three of the sample companies did sign it, Techniker Krankenkasse, MaibornWolff $\mathrm{GmbH}$ and salesforce.com Germany GmbH (Charta der Vielfalt, 2021). Nonetheless, no mention of external support of a foundation, charter or initiative could be found on the websites of these companies during the analysis. Therefore, a recommendation for the respective companies is to confidently declare on their websites that they support the Charta der Vielfalt. Likewise, a comparable declaration could be made through posts on Instagram. Similarly, initiatives like "She for IT" on the website of adesso SE (see figure 4) show that a company takes inclusion and diversity management seriously and that diverse groups have career prospects there. Companies that take diversity management seriously could therefore consider being bolder in their communication and communicate straightforward that they desire and support diverse employees. Regarding the discussion of the second hypothesis, organisations should 


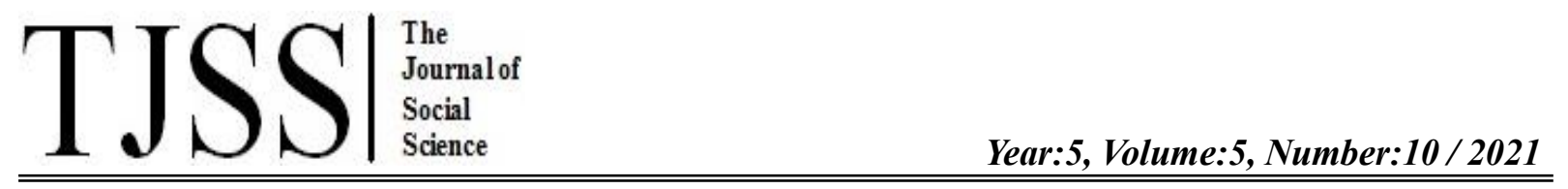

specifically consider people with disabilities and people from the LGBTQIA+ community in this kind of upfront recruitment of diverse employees.

Figure 1: Initiative for the inclusion of female IT employees on the website of adesso SE

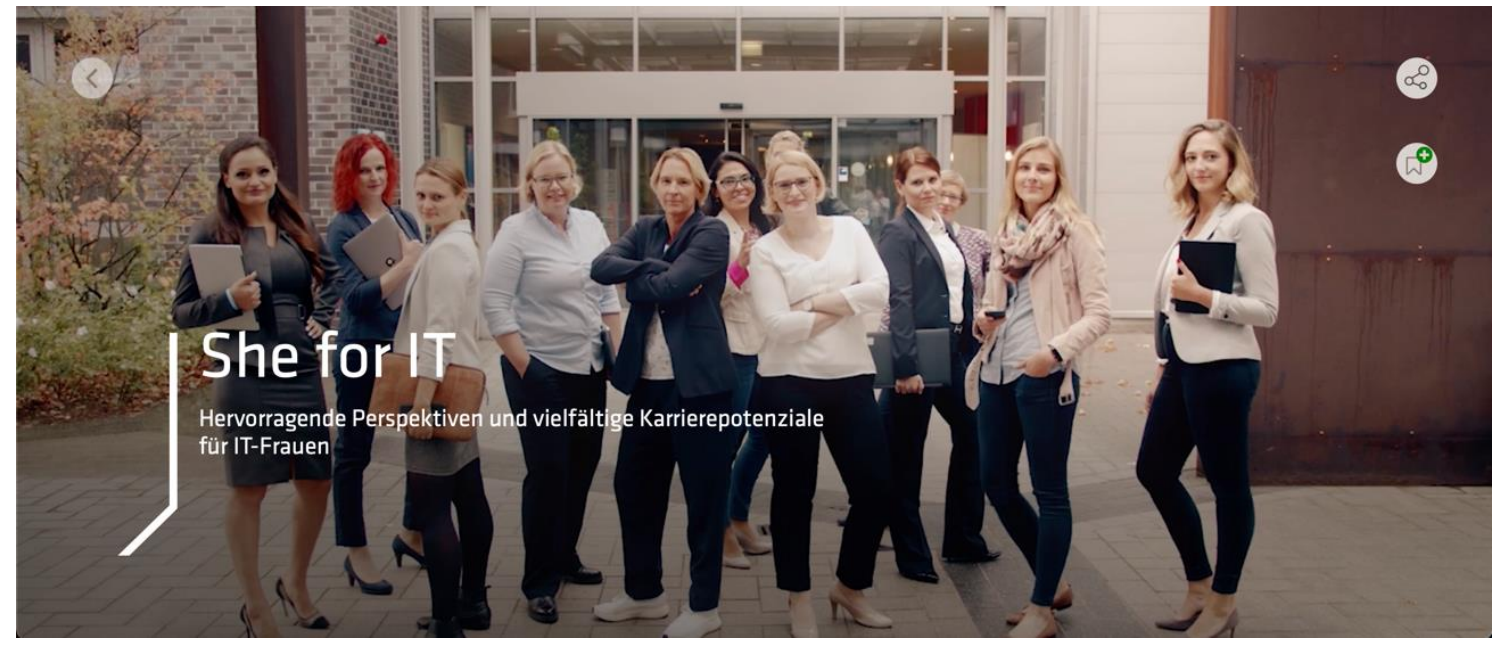

Note: Screen capture of "She for IT" by adesso SE, n.d.

Finally, coming to the limitations of the study, while the hypotheses and codebook were carefully defined and the coding process strictly adhered to, the study also has its weaknesses. One weakness of the study is that the category 'diversity: gender' only contains male and female as gender while there is no diverse gender option, making it not very inclusive. This was chosen for the study, because nonbinary and trans people are not necessarily recognisable as such in pictures. Furthermore, it is not certain that the subjects in the pictures classified as men or women really do have the gender that was identified. Yet, as the majority of people in Germany do identify with their gender and do not change their gender either (judging from the share of LGBTQIA+ individuals in Germany), this issue is not seen as very problematic for the study. Another limitation of the study is the lack of a benchmark for people of colour that shows pictures to help coders decide which ethnicity to code. Such a benchmark would have increased inter-coder reliability. Nonetheless, this doesn't pose a big problem for the study, because there was only one coder. Regarding the representativity of the study, considering that there were about 3.28 million companies in Germany in 2018 (Statistisches Bundesamt, 2020b) the sample of twelve companies cannot be seen as representative regarding all German companies. However, considering the scope of the article, representativity was no goal of the study. Instead, it delivers an interesting overview about the diversity communication of some of Germanys best employers.

\section{CONCLUSION}

According to the theories presented in this article, organisations' external diversity communication, such as diverse imagery and gender-neutral language could influence their stakeholders. The quantitative analysis of media content that analysed the external communication of twelve German companies that are part of Germanys' best employers resulted in the following main learnings:

- There seems to be a difference between how companies express diversity on their website and on social media.

- Inclusive language is not yet widely used by companies.

- Companies apparently focus their diversity on gender equality and inclusion of people of colour while there seem to be less diversity measures regarding people with disabilities and members of the LGBTQIA+ community.

- Diversity is not dependent on company size. 
Regarding the research question, 'How do organisations in Germany communicate their diversity externally, on their websites and social media?', the study found that the analysed German organisations do communicate diversity, with a focus on gender equality and equality of people of different ethnicities. Members of the LGBTQIA+ community and people with disabilities are mostly left out of the communication. Furthermore, the analysed companies communicate diversity differently on their website and on Instagram, being bolder on social media than on their website regarding inclusive language, while mentioning internal diversity commitments rather on their website than on social media. Because the study's sample wasn't representative the results cannot refer to all German organisations. Still, they provide a good overview about the diversity communication of some of Germany's best employers. The results of this study could therefore be helpful for the companies that were part of the sample, as the results and the discussion show where they could improve their communication in order to be more diverse, which is specifically being bolder and more straightforward regarding their potential interest in diverse talents. As elaborated in the article, a more diverse communication could positively influence the perception of the companies' stakeholders towards diverse people. Moreover, as applicants actively search for diverse companies, a more inclusive communication could lead to more diverse teams within these organisations. Diverse teams can potentially have many advantages for organisations, among others, more creativity and innovation. Therefore, an increased effort of organisations to make their communication more diverse and inclusive can not only potentially have positive impacts on the stakeholders but could also lead to more innovations.

In conclusion, there is still a lot of possible research to be done in the field of external diversity communication in Germany and companies are still a long way from having really diverse communication. Yet, as this analysis found, the external communication of some German companies is already more diverse than expected, which is a positive sign and possibly shows the current and future trend towards more diverse companies, more diverse communication and, potentially, a more openminded society.

\section{REFERENCES}

adesso SE. (n.d.). She for IT [screen capture]. Retrieved January 21, 2021, from https://www.adesso.de/de/unternehmen/she-for-it/index.jsp

Åkestam, N., Rosengren, S. \& Dahlen, M. (2017). Advertising "like a girl": Toward a better understanding of "femvertising" and its effects. Psychology \& Marketing 34(8), 795-806. Retrieved January 11, 2021, from https://doi.org/10.1002/mar.21023 [11.01.2021]

Al-Sheik Hussein, B. (2012). The Sapir-Whorf Hypothesis today. Theory and Practise in Language Studies, 2(3), 642-646. Retrieved November 16, 2020, from doi:10.4304/tpls.2.3.417-429

Antidiskriminierungsstelle des Bundes. (2017). Ergebnisse der Studie “Out im Office?!”. Erste Ergebnisse zur Arbeitssituation lesbischer, schwuler, bisexueller und Trans*-Beschäftigter in Deutschland. $\quad$ Retrieved $\quad$ October 20, 2020, from https://www.antidiskriminierungsstelle.de/SharedDocs/Downloads/DE/publikationen/Umfrage n/20170719 Umfrageergebnisse Out im Office.pdf;jsessionid=0908F9A7C639995D25FB44 6A31BA23CE.2_cid341? blob=publicationFile \&v=2

Bandura, A. (2001). Social cognitive theory of mass communication. Mediapsychology, 3, 265-299. Retrieved January 11, 2021, from DOI:10.1207/S1532785XMEP0303_03 
Bell, M. P., Özbilgin, M. F., Beauregard, T. A. \& Sürgevil, O. (2011). Voice, silence and diversity in $21^{\text {st }}$ century organizations: Strategies for inclusion of gay, lesbian, bisexual and transgender employees. Human Resource Management, 50(1), 131-146. Retrieved November 11, 2020, from https://eprints.mdx.ac.uk/19110/1/HRM voice final\%20-\%20Word\%20version.pdf

Berger-Grabner, D. (2016). Wissenschaftliches Arbeiten in den Wirtschafts- und Sozialwissenschaften. Hilfreiche Tipps und praktische Beispiele ( $3^{\text {rd }}$ edition). Wiesbaden: Springer Gabler.

Bigler, R. S. \& Leaper, C. (2015). Gendered language: Psychological principles, evolving practices, and inclusive policies. Policy Insights from the Behavioral and Brain Sciences 2(1), 187-194. Retrieved November 11, 2020, from doi: 10.1177/2372732215600452

Brosius, H.-B., Koschel, F. \& Haas, A. (2009). Methoden der empirischen Kommunikationsforschung ( $5^{\text {th }}$ edition). Wiesbaden: GWV

Bradley, E. D. (2020). The influence of linguistic and social attitudes on grammaticality judgements of singular 'they'. Language Sciences, 78. Retrieved November 16, 2020, from doi: 10.1016/j.langsci.2020.101272

Bundesagentur für Arbeit. (2019). Arbeitsmarkt für Menschen mit Behinderung (Jahreszahlen). Retrieved January 1, 2021, from https://statistik.arbeitsagentur.de/Statistikdaten/Detail/201812/analyse/analyse-arbeitsmarktschwerbehinderte/analyse-arbeitsmarkt-schwerbehinderte-d-0-201812pdf.pdf?__blob=publicationFile

Charta der Vielfalt. (n.d.) Die Diversity Dimensionen [graph]. Retrieved December 8, 2020, from https://www.charta-der-vielfalt.de/diversity-verstehen-leben/diversity-dimensionen/

Charta der Vielfalt. (2020). Diversity Trends. Die Diversity-Studie 2020. Retrieved December 9, 2020, from https://www.diversity-trends.de/\#inhalt

Charta der Vielfalt. (2021). Unterzeichner_innen der Charta der Vielfalt. Retrieved January 21, 2021, from https://www.charta-der-vielfalt.de/ueber-uns/die-unterzeichner-innen/liste/

Dalia. (2016). Counting the LGBT population: 6\% of Europeans identify as LGBT. Retrieved January 1, 2021, from https://daliaresearch.com/blog/counting-the-lgbt-population-6-of-europeansidentify-as-lgbt/

Deloitte. (2015). The radical transformation of diversity and inclusion. The millennial influence. Retrieved January 11, 2020, from https://launchbox365.com/wp-content/uploads/2017/03/usinclus-millennial-influence-120215.pdf

Duden. (2020a). Mitarbeiterin, die. Retrieved November 23, 2020, from https://www.duden.de/rechtschreibung/Mitarbeiterin

Duden. (2020b). Studierende. Retrieved November 23, 2020, from https://www.duden.de/rechtschreibung/Studierende

Duff, A. (2011). Big four accounting firms' annual reviews: A photo analysis of gender and race portrayals. Critical Perspectives on Accounting (22), p. 20-38. Retrieved December 2, 2020, from https://sci-hub.tf/10.1016/j.cpa.2010.05.001 
Ettel, A. \& Zschäpitz, H. (2020). Immer weniger Ausländer in Deutschen Konzernspitzen. Welt. Retrieved October 15, 2020, from https://www.welt.de/wirtschaft/karriere/article217092008/Groesste-deutsche-UnternehmenKonzernspitzen-zunehmend-wieder-rein-deutsch.html

elDiario. (2016). 'Purple washing' o acordarse del feminismo cuando interesa. Retrieved January 11, 2021, from https://www.eldiario.es/opinion/zona-critica/burkini-barbijaputa-purplewashing_129_3856618.html

Faßmann, M. \& Moss, C. (2016). Instagram als Marketing-Kanal. Die Positionierung ausgewählter Social-Media-Plattformen. Wiesbaden: Springer VS.

Ferdman, B. M. (2014). The practice of inclusion in diverse organisations. Toward a systemic and inclusive framework. In Ferdman, B. M. \& Deane, B. R. (Eds.), Diversity at work. The practice of inclusion. Retrieved November 28, 2020, from https://intel-writers.us/wpcontent/uploads/2019/12/Parise-for-the-Diversity-of-WOrk-for-Chapter-15-Analysis-EssayAssignment.pdf\#page $=100$

Forbes. (2017). Dove invented 'femvertising' but its latest stunt didn't wash with consumers. Retrieved January 11, 2021, from https://www.forbes.com/sites/avidan/2017/05/11/dove-inventedfemvertising-but-its-latest-stunt-didnt-wash-with-consumers/?sh=2523594056b6

Gentner, D. (2016). Language as cognitive tool kit: How language supports relational thought. American Psychologist, 71(8), 650-657. Retrieved November 16, 2020, from https://groups.psych.northwestern.edu/gentner/papers/Gentner 2016-Toolkit.pdf

Gustafsson Sendén, M., Bäck, E. A. \& Lindqvist, A. (2015). Introducing a gender-neutral pronoun in a natural gender language: The influence of time on attitudes and behaviour. Frontiers in Psychology, 6(893), 8-12. Retrieved November 16, 2020, doi: 10.3389/fpsyg.2015.00893

Hansen, K. (2014). CSR und Diversity Management. Management-Reihe Corporate Social Responsibility. Heidelberg: Springer Verlag.

Hansen, K. \& Seierstad, C. (2017). Corporate social responsibility and diversity management. Theoretical approaches and best practices. Switzerland: Springer International Publishing.

Hayles, R. (2014). Communicating about inclusion. In Ferdman, B. M. \& Deane, B. R. (Eds.), Diversity at work. The practice of inclusion. Retrieved October 15, 2020, from https://intel-writers.us/wpcontent/uploads/2019/12/Parise-for-the-Diversity-of-WOrk-for-Chapter-15-Analysis-EssayAssignment.pdf\#page $=100$

Ivanov, C., Lange, M. B., Tiemeyer, T. \& Ptok, M. (2019). Geschlechtergerechte Sprache in der Wissenschaft. Gebrauch und Motivation. Gender(ed) Thoughts, Working Paper Series (2). Retrieved November 28, 2020, from http://www.gendered-thoughts.unigoettingen.de/fileadmin/user_upload/genderedthoughts_vol02 ivanov et al 2019.pdf

Kipman, U., Leopold-Wildburger, U. \& Reiter, T. (2018). Wissenschaftliches Arbeiten 4.0. Vortragen und Verfassen leicht gemacht. Berlin: Springer-Verlag.

Kolek, V. (2019). Discourse of non-heteronormative labelling in German-language press: The case of Gendersternchen. Slovenščina 2.0, 7(2), 118-140. Retrieved November 23, 2020, from https://doi.org/10.4312/slo2.0.2019.2.118-140 
Lammenett, E. (2019). Praxiswissen Online-Marketing. Affiliate-, Influencer-, Content-, und E-MailMarketing, Google Ads, SEO, Social Media, Online-inklusive Facebook-Werbung $\left(7^{\text {th }}\right.$ edition). Wiesbaden: Springer Gabler.

Maier, C. D., \& Ravazzani, S. (2019). Bridging diversity management and CSR in online external communication. Corporate Communications, 24(2), 269-286. Retrieved October 15, 2020, from https://doi.org/10.1108/CCIJ-01-2018-0015

McKinsey \& Company. (2018). Delivering through diversity. Retrieved December 9, 2020, from https://www.mckinsey.com/ /media/mckinsey/business\%20functions/organization/our\%20ins ights/delivering\%20through\%20diversity/delivering-through-diversity_full-report.pdf

NapoleonCat. (2021). Distribution of Instagram users in Germany as of December 2020, by age and gender of users [graph]. Statista. Retrieved January 11, 2021, from https://www.statista.com/statistics/1021961/instagram-users-germany-age-gender/

Nishii, L. H. \& Özbilgin, M. F. (2007). Global diversity management: Towards a conceptual framework. Retrieved October 11, 2020, from https://digitalcommons.ilr.cornell.edu/cgi/viewcontent.cgi?article=2265\&context=articles

Offizielles Stadtportal der Hansestadt Lübeck. (2019). Lübeck führt einheitliche geschlechtergerechte Sprache ein. Retrieved November 28, 2020, from https://www.luebeck.de/de/presse/pressemeldungen/view/134698

Onlinemarketing.de. (2020). Authentische Darstellung der LGBTQ+ Community: Getty Images und GLAAD erklären, wie es geht. Retrieved January 13, 2021, from https://onlinemarketing.de/cases/authentische-darstellung-lgbtq-community-getty-imagesglaad-interview

PageGroup. (2018). Diversity Management Studie 2018. Retrieved December 8, 2020, from https://www.michaelpage.de/sites/michaelpage.de/files/DE Diversity Management Study DI GITAL.pdf

Pless, N., \& Maak, T. (2004). Building an inclusive diversity culture: Principles, processes and practice. Journal of Business Ethics, 54, 129-147. Retrieved October 15, 2020, from https://www.researchgate.net/publication/36383581_Building_an_Inclusive_Diversity_Cultur e_Principles_Processes_and_Practice/link/5481902c0cf22525dcb62278/download

Presseportal. (2020). Das sind sie: Deutschlands beste Arbeitgeber 2020. Retrieved October 12, 2020, from https://www.presseportal.de/pm/69829/4531843

Ravazzani, S. (2016). Understanding approaches for managing diversity in the workplace: An empirical investigation in Italy. Equality, Diversity and Inclusion, 35(2), 154-168. Retrieved October 15, 2020 ,

from http://pure.au.dk/portal/files/117636559/Understanding approaches to managing diversity i n the workplace postprint 2016.pdf

Riffe, D., Lacy, S. \& Fico, F. G. (2005). Analysing media messages: Using quantitative content analysis in research $\left(2^{\text {nd }}\right.$ edition). London: Lawrence Erlbaum

Roland Berger Stragegy Consultants. (2012). Diversity \& Inclusion. Eine betriebswirtschaftliche Investition. Retrieved December 7, 2020, from https://www.cssa- 
wiesbaden.de/fileadmin/Dokumente/Demografischer_Wandel/Dokumente/Diversity/Diversity and Inclusion Roland Berger D 20120716.pdf

Rössler, P. (2017). Inhaltsanalyse ( $3^{\text {rd }}$ edition). Konstanz: UVK Verlagsgesellschaft.

Sczesny, S., Moser, F. \& Wood, W. (2015). Beyond sexist beliefs: How do people decide to use genderinclusive language? Personality and Social Psychology Bulletin, 41(7), 943-954. Retrieved November 16, 2020, doi: 10.1177/0146167215585727

Shutterstock premier. (2018). Visualizing diversity in advertising around the world. How marketers are thinking about and using diverse images in their content and campaigns. Retrieved December 9, 2020, from https://advertising.report/Resources/Whitepapers/LP/4a61fb03-bdbd-4da5-83c6b45f6a5390f5_Visualizing-Diversity-in-Advertising---Shutterstock.pdf

Stangel-Meseke, M. (2017). Influencing employer attractiveness by connecting corporate social responsibility and diversity management. In K. Hansen (editor) CSR und Diversity Management. Erfolgreiche Vielfalt in Organisationen. Heidelberg: Springer Gabler.

Statistisches Bundesamt. (2018). Arbeitsmarkt auf einen Blick. Deutschland und Europa. Retrieved January 1, 2021, from: https://www.destatis.de/Europa/DE/Publikationen/BevoelkerungArbeit-Soziales/Arbeitsmarkt/broeschuere-arbeitsmark-blick0010022189004.pdf?_blob=publicationFile

Statistisches Bundesamt. (2020a). Deutsche und nichtdeutsche Bevölkerung nach Geschlecht; Deutschland. Retrieved January 1, 2021, from: https://www.destatis.de/DE/Themen/GesellschaftUmwelt/Bevoelkerung/Bevoelkerungsstand/Tabellen/deutsche-nichtdeutsche-bevoelkerungnach-geschlecht-deutschland.html

Statistisches Bundesamt. (2020b). Anzahl der Unternehmen* in Deutschland von 2002 bis 2018 [graph]. Statista. Retrieved January 4, 2021, from https://de.statista.com/statistik/daten/studie/246358/umfrage/anzahl-der-unternehmen-indeutschland/

Süß, S. (2008). Diversity-Management auf dem Vormarsch. Eine empirische Analyse der deutschen Unternehmenspraxis. Schmalenbachs Z betriebswirtschaftliche Forschung (60), 406-430. Retrieved January 14, 2021, from https://doi.org/10.1007/BF03372800

Tavits, M. \& Pérez, E. O. (2019). Language influences mass opinion toward gender and LGBT equality. Retrieved November 23, 2020, from https://www.pnas.org/content/pnas/116/34/16781.full.pdf

Trittin, H. \& Schoeneborn, D. (2017). Diversity as polyphony: Reconceptualizing diversity management from a communication-centered perspective. Journal of Business Ethics. Retrieved October 15, 2020 , from https://www.researchgate.net/profile/Dennis Schoeneborn/publication/283897355 Diversity as_Polyphony_Reconceptualizing_Diversity_Management_from_a_CommunicationCentered_Perspective/links/579a1cc708ae7b940a8a92d2/Diversity-as-PolyphonyReconceptualizing-Diversity-Management-from-a-Communication-Centered-Perspective.pdf

Vedder \& Krause. (2014). Corporate Social Responsibility und Diversity Management - eine Win-WinSituation. In K. Hansen (editor) CSR und Diversity Management. Erfolgreiche Vielfalt in Organisationen. Heidelberg: Springer Gabler. 
Völklinger Kreis. (2015). Diversity Management in Deutschland 2015. Retrieved December 7, 2020, from Völklinger $\quad$ Kreis, 2015: https://www.vkonline.de/index.php?eID=dumpFile \& $\mathrm{t}=\mathrm{f} \& \mathrm{f}=8131 \&$ token $=\mathrm{aed} 687757 \mathrm{cc} 253 \mathrm{dcf} 270339 \mathrm{aa} 51 \mathrm{f} 8 \mathrm{a}$ $\underline{3 \mathrm{c} 4 \mathrm{a} 163693}$

Von Bergen, C. W., Soper, B. \& Foster T. (2002). Unintended negative effects of diversity management. In Public Personnel Management, 31.2, 239-251. Retrieved October 11, 2020, from http://nreilly.asp.radford.edu/von\%20bergen\%20et\%20al\%202002.pdf

We Are Social, Hootsuite \& DataReportal. (2020). Most popular social networks worldwide as of October 2020, ranked by number of active users (in millions) [graph]. Statista. Retrieved January 11, 2021, from https://www.statista.com/statistics/272014/global-social-networksranked-by-number-of-users/ 